\title{
Bone tuberculosis in Roman Period Pannonia (western Hungary)
}

\author{
Tamás Hajdu'1/+ , Erzsébet Fóthi ${ }^{2}$, Ivett Kővári ${ }^{3}$, Mónika Merczi ${ }^{4}$, Attila Molnár ${ }^{5}$, \\ Gábor Maász ${ }^{6,7}$, Péter Avar6, Antónia Marcsik ${ }^{8}$, László Márk ${ }^{6,7}$ \\ 'Department of Biological Anthropology, Institute of Biology, Faculty of Science, Eötvös Loránd University, Budapest, Hungary \\ ${ }^{2}$ Department of Anthropology, Hungarian Natural History Museum, Budapest, Hungary ${ }^{3}$ Department of Archaeology, \\ Herman Ottó Museum, Miskolc, Hungary ${ }^{4}$ Department of Archaeology, Balassa Bálint Museum, Esztergom, Hungary \\ ${ }^{5}$ Department of Archaeology, Xántus János Museum, Győr, Hungary ${ }^{6}$ Department of Analytical Biochemistry,

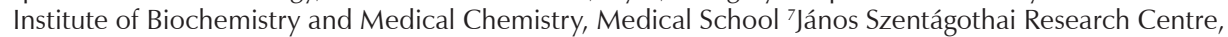 \\ University of Pécs, Pécs, Hungary ${ }^{8}$ Independent consultant
}

The purpose of this study was to analyse a skeleton (adult female, 25-30 years) that presented evidence of tuberculous spondylitis. The skeleton, dated from the Roman Period (III-VI centuries), was excavated near the town of Györ, in western Hungary. The skeleton was examined by gross observation supplemented with mycolic acid and proteomic analyses using MALDI-TOF/TOF tandem mass spectrometry. The biomolecular analyses supported the morphological diagnosis.

Key words: spinal tuberculosis - mycolic acid analysis - proteomic analysis

Paleopathology is an important branch of physical anthropology, it involves the study of injuries and disease processes in ancient human populations. Infectious diseases are the most significant selective factors affecting human populations and they cause the most important pathological processes resulting in changes in bones. Specific bacterial causes of disease are associated with characteristic bone lesions that do not occur with infection caused by other bacterias. Examples of such infections include tuberculosis (TB), treponematosis and leprosy (Manchester 1983).

Estimating the exact prevalence of skeletal TB in ancient populations is very difficult. Approximately 5\% of chronic TB cases show typical lesions in the skeleton (Donoghue et al. 2004). Moreover, the results of the examination of a skeleton can be influenced by post-mortem damage to the skeletal remains resulting from burial. This paper presents the investigation of a skeleton that displayed changes suggestive of tuberculous spondylitis.

In 2009, three skeletons from the Roman Period (second half of the III-IV centuries) were excavated in Györ, in western Hungary (Györ-Frigyes Laktanya site). These skeletons were found at a smaller settlement located near Arrabona, along the trade route between Arrabona and Savaria, another Roman settlement. Arrabona was built on the site of a modern-day town and an earlier Celtic settlement and it was one of the most important auxiliary Roman forts of the Danube Limes (Gabler 1967, Visy 2003a,

Financial support: Faculty of Medicine Research Fund (AOK-KA 34039-11/2009, AOK-KA 2011), University of Pécs, the Hungarian National Scientific Research Foundation (OTKA K72592, D048294, CNK 78480), TIOP 1.3.1-10/1-2010-0008, TIOP 1.3.1-07/1

+ Corresponding author: hajdut@elte.hu

Received 13 January 2012

Accepted 10 September 2012 b). The skeletal materials were kept in the Xántus János Museum in Győr. Morphological sex was determined and the age at death was estimated by the recommendations of Rösing et al. (2007). The paleopathological analysis was conducted by gross observation (Ortner 2003).

Of the three specimens, one (KE69, male, 35-50 years old) showed no pathological changes in the skull or postcranial bones. Another (KE90, female, 25-35 years old) had no pathological lesions in the skull, but had nonspecific changes in the bones of the lower limbs. This skeleton showed slight periostitis on the medial surface of the left tibia and osteomyelitis in the right tibia, at the nutrient foramen.

The third specimen (KE91), a complete skeleton of a 25-30-year-old female, had severe and distinctive lesions. The skeleton was well preserved and all the bones could be examined. Changes indicative of spinal TB were limited to certain sections of the spine, such as the thoracic region. The anterior and lateral surfaces of all the vertebral bones showed slight hypervascularisation and porosity was noted on these surfaces as well as on the upper and lower intervertebral plates. The porosity and hypervascularisation were more pronounced in the thoracic and lumbar vertebrae. Hypertrophic bone formation was observed in the second and third thoracic vertebrae (T2-T3) and marginal lipping, porosity and bone reaction were observed in the T4-T5 vertebral bodies. The most characteristic pathological changes were seen in the third and fourth thoracic vertebrae (Figs 1,2). Reactive bone formation was also observed, as well as a large lytic focus in the vertebral bodies (Figs 3-6). The affected section of the spinal column showed no evidence of marked collapse or gibbous deformity and only a slight angulation was observed. The neural arches of the third and fourth thoracic vertebrae were not affected. Osteolytic changes and periosteal reaction in these thoracic vertebrae suggest an active-stage infectious process, most likely of tuberculous aetiology. Other pathological lesions included slight hypervascularisation on anterior and posterior sur- 
faces of the sternum and periostitis on the femora, tibiae and fibulae. These changes may be associated with TB. Other observed lesions, including degenerative arthritis in the shoulder joints, incomplete spondylolysis in the fifth lumbar vertebra and a healed oblique fracture of the distal left ulnar shaft, are not associated with TB. There were no pathological lesions on the endocranial and ectocranial surfaces of the skull or on the ribs.

Regarding the morphological changes in the spine that were suggestive of tuberculous spondylitis, several differential diagnoses could be considered: fracture, osteoporosis, brucellosis, metastatic cancer, staphylococcal infection or osteomyelitis. To clarify the exact aetiology of the skeletal changes, biomolecular analysis was performed on skeletal samples from the KE69, KE90 and KE 91 specimens.

Samples of ancient mycolic acids and Mycobacterium tuberculosis specific proteins were investigated by mass spectrometry to provide additional molecular evidence of mycobacterial infection. The sample preparation and mass spectrometric analysis of lipid and protein biomarkers

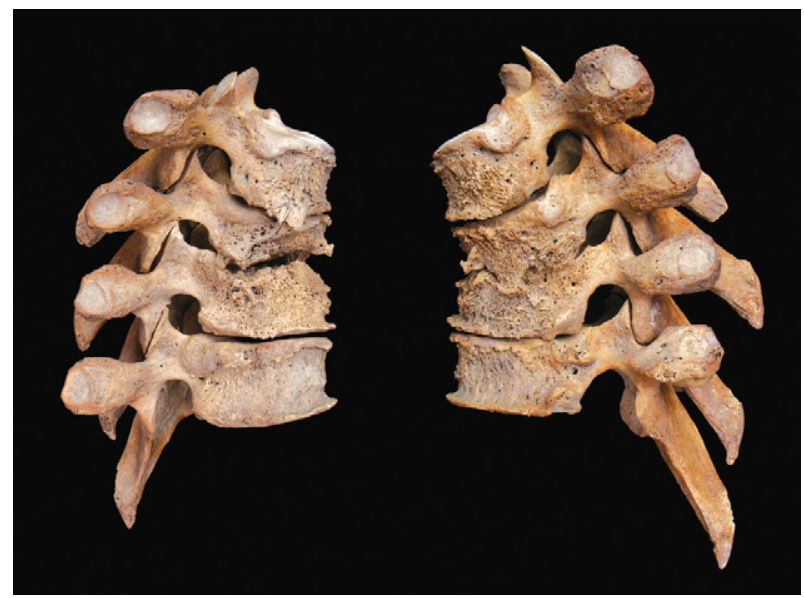

Fig. 1: the right and left lateral view of the thoracic vertebrae T2-T5.

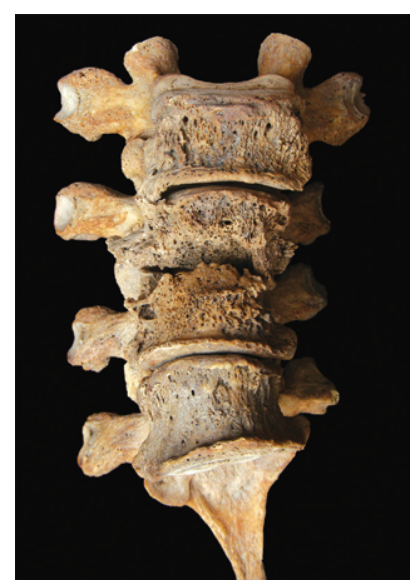

Fig. 2: the anterior view of the thoracic vertebrae T2-T5. were conducted as previously described (Márk et al. 2010, 2011, Boros-Major et al. 2011). Briefly, $65 \mathrm{mg}$ of crude bone powder was decalcified with $1 \mathrm{~mL}$ of $0.5 \mathrm{M}$ ethylenediamine tetraacetic acid $(\mathrm{pH}=8.0)$ and extracted with $100 \mu \mathrm{L}$ of $6 \mathrm{M}$ guanidine- $\mathrm{HCl}$ in $0.1 \mathrm{M}$ Tris $(\mathrm{pH}=7.5)$ at room temperature. The extracted proteins were separated by sodium dodecyl sulfate polyacrylamide gel electrophoresis and in-gel enzymatic hydrolysis of the proteins of interest was achieved using a trypsin solution. Proteomic analysis was conducted using peptide mass fingerprinting and direct sequencing of single charged monoisotopic peaks of the tryptic peptides. Mycolic acids and their derivatives were extracted from $100 \mathrm{mg}$ of bone powder with $200 \mu \mathrm{L}$ chloroform-methanol $(80 / 20 \mathrm{v} / \mathrm{v})$ mixture in an ultrasonic bath with an extraction time of $10 \mathrm{~min}$. A mixture of $3 \mu \mathrm{L}$ of extract or control standard solution with an equal volume of a 2.5-dihydroxybenzoic acid matrix solution was loaded onto the target plate (MTP 384 massive target T, Bruker Daltonics, Bremen, Germany). Several peptide fragments of mycobacterial proteins, including a fumarate reductase flavoprotein subunit (gi:15608690) and adenylate kinase (gi:15607873), were identified from the bone samples. The results of the proteomic analysis to identify mycobacterial proteins are summarised in Table.

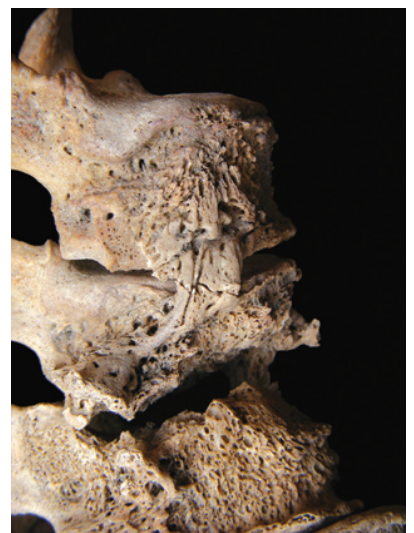

Fig. 3: detailed view of the major lytic focus in the affected vertebrae.

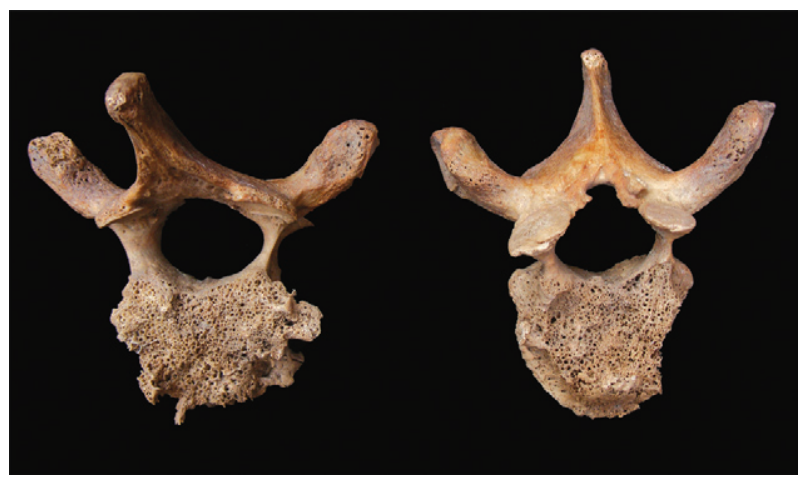

Fig. 4: the inferior view of the third thoracic vertebra and superior view of the fourth thoracic vertebra. 
Specific mycobacterial lipid biomarkers were detected by MALDI-TOF/TOF MS in the KE91 sample, providing further support for the hypothesis of a tuberculous aetiology. In our extracts, both positively charged monoisotopic peaks of free mycolic acids (Figs 7,8) and fragments of trehalose mycolates were observed (Figs 9, 10) (Shui et al. 2007). Our mass spectrometry results showed significant M. tuberculosis infection in the investigated skeletal remains. The KE69 and KE90 samples tested negative for the presence of M. tuberculosis (Fig. 7).

Many cases of osseous TB have been discovered in different regions of Europe. Published cases suggest that TB was widespread in Europe in the VII-VIII centuries and XIV-XVII centuries (Pálfi et al. 1999, Roberts \& Buikstra 2003, Stone et al. 2009).

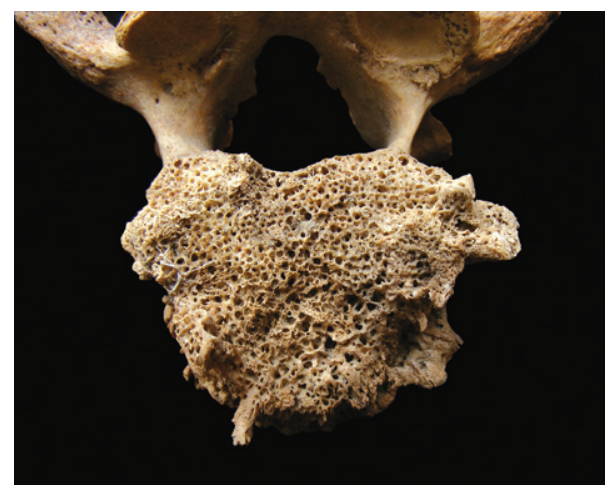

Fig. 5: detailed view of the inferior surface of third thoracic vertebra.
The elevated frequency of skeletal TB in the ancient populations of Hungary (predominantly on the Great Plain of eastern Hungary) has been a focus of investigation for years. These cases are primarily from the VII-IX centuries AD (Avar period) and later (Pálfi \& Marcsik 1999, Marcsik et al. 2006). A case of hypertrophic osteoarthropathy consistent with TB has been described in a Late Neolithic (4790-4594 BC) population (Masson et al. 2008). Another specimen, from the Late Neolithic Period (5th millennium BC), was reported to have signs of Pott's disease (Köhler et al. 2012). To date, there has been only one case of spinal TB (lumbosacral TB) dating from the II-V centuries (Sarmatian Period) (Szelek-

A

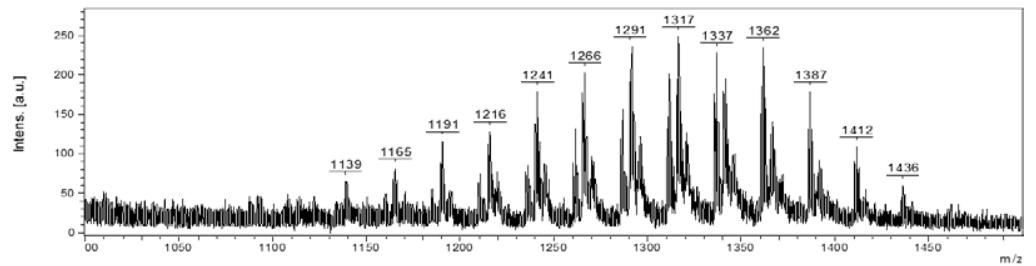

B

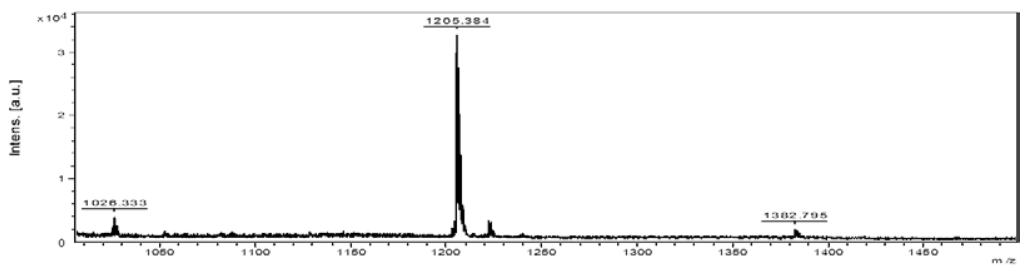

C

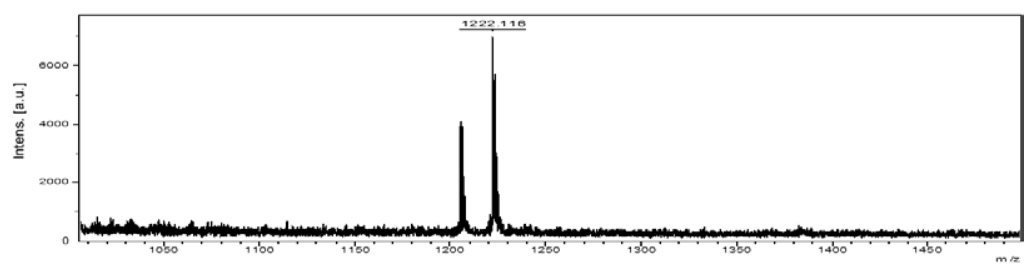

Fig. 7: characteristic MALDI-TOF mass spectrum of the investigated archaeological skeletal remains. Each sample (100 mg) and the 2.5-DHB matrix $(10 \mathrm{mg})$ were dissolved in $1 \mathrm{~cm}^{3}$ of chloroform-methanol $(8 / 2 \mathrm{v} / \mathrm{v})$ mixture. The ions were accelerated under delayed extraction conditions $(180$ $\mathrm{ns}$ ) in positive ion mode with an acceleration voltage of $20.00 \mathrm{kV}$ each spectrum was detected by reflectron detector. A: Mycobacterium tuberculosis infected sample (KE91); B: the KE69 skeletal remain; C: the KE90 finding. In last two cases the presence of mycolic acids were not detected. 
ovszky \& Marcsik 2010). Cases of skeletal TB have also been reported in western Hungary (Transdanubia), including the earliest reported case, from the Roman Period (340-430 AD) (Merczi 2001) and later cases (IX-XII centuries) (Évinger et al. 2011). Spinal TB has been observed in mummified individuals and in excavated dry skeletons from the XVIII-XIX centuries (Pap et al. 1999, Fletcher et al. 2003a, b, Szikossy et al. 2010).

Although there is little published evidence of TB in Hungary before the Roman Period, skeletal TB may have been present in Hungary at that time. During the Roman Period, urbanisation and an increase in public utilities, new living conditions and an increased population density in Hungary and throughout the Roman Empire may have led to the dissemination of infectious diseases including TB (Nagy 2003). Based on this pro- cess of urbanisation, one might presume that skeletons with TB would be discovered with greater frequency in the osteoarcheological findings of excavations of Roman-Period cemeteries in western Hungary. However, paleopathological investigations of such materials have not yet been performed. This case of skeletal remains with evidence of spinal TB (presumed morphologically and confirmed by biomolecular analyses) contributes to available knowledge of the health of Roman-Period populations and the morphological aspects of bone TB. Our results show that biomolecular investigations are of vital importance for precise diagnosis and should be included as routine procedures in paleopathological investigations (Taylor et al. 1996, Zink et al. 2001, Fletcher et al. 2003a, b, Donoghue et al. 2005, Hershkovitz et al. 2008, Évinger et al. 2011, Hajdu et al. 2012).

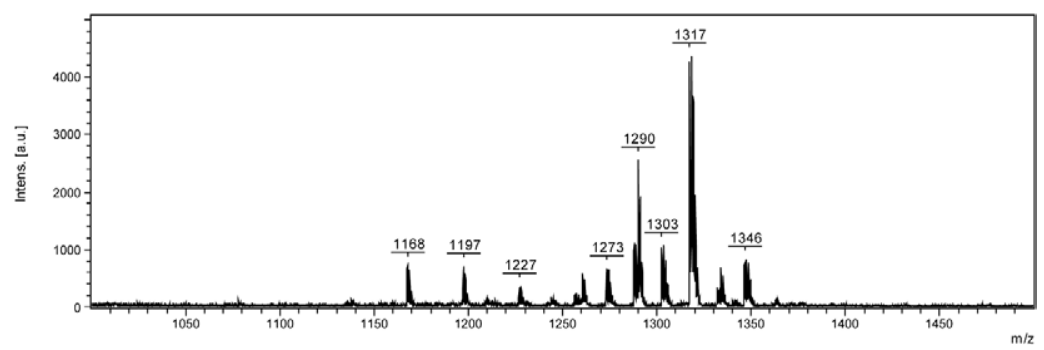

Fig. 8: characteristic MALDI-TOF mass spectrum of mycolic acid standard (Mycobacterium tuberculosis human strain, CAS 37281-34-8, Cat. M4537) from Sigma-Aldrich Kft (Budapest, Hungary).

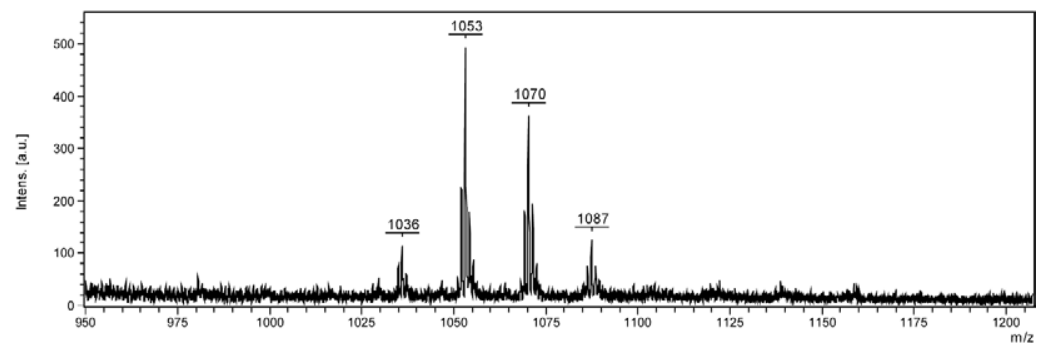

Fig. 9: characteristic MALDI-TOF mass spectrum of fragments of trehalose mycolates from archaeological remain. Mass spectrometric conditions as indicated in Fig. 7 were used.

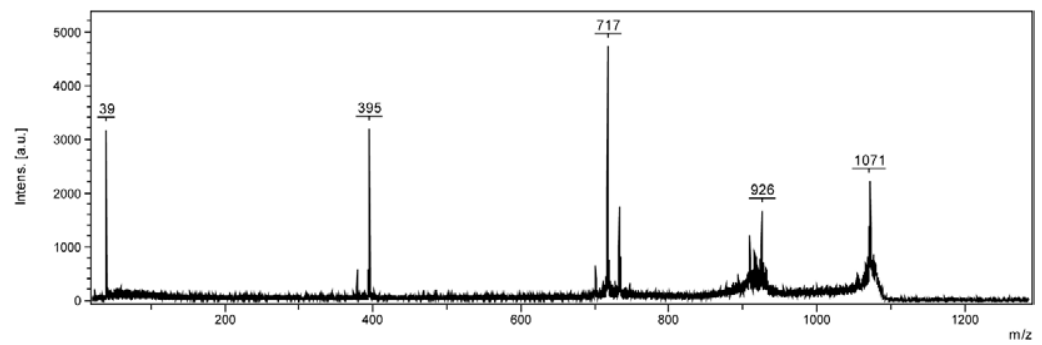

Fig. 10: characteristic MALDI-TOF/TOF PSD fragmentation of $\mathrm{m} / \mathrm{z} 1071$ as precursor ion. The mass spectrum shows the fragment of the mycolic acid skeleton $(\mathrm{m} / \mathrm{z} 717,48: 2)$ after the fragmentation of trehalose unit and the $\mathrm{m} / \mathrm{z} 395$ peak indicates the presence of alfa-MA chain. 
TABLE

Proteomic parameters of the identified mycobacterial proteins of the archaeological skeletal remain

\begin{tabular}{|c|c|c|c|c|c|}
\hline Protein & Accession & $\begin{array}{c}\text { Theoretical } \\
\text { molecular } \\
\text { weight (Da) }\end{array}$ & $\begin{array}{l}\text { Mascot } \\
\text { score }\end{array}$ & $\begin{array}{l}\text { Peptides } \\
\text { matched }\end{array}$ & $\begin{array}{l}\text { Sequence } \\
\text { coverage } \\
(\%)\end{array}$ \\
\hline $\begin{array}{l}\text { Fumarate reductase } \\
\text { flavoprotein subunit } \\
\text { (Mycobacterium tuberculosis) }\end{array}$ & gi:15608690 & 63723 & 136 & 17 & 31 \\
\hline $\begin{array}{l}\text { Adenylate kinase } \\
\text { (M. tuberculosis) }\end{array}$ & gi:15607873 & 20113 & 183 & 12 & 55 \\
\hline
\end{tabular}

experimental conditions were mentioned in the text.

\section{REFERENCES}

Boros-Major A, Bóna Á, Lovász G, Molnár E, Marcsik A, Pálfi Gy, Márk L 2011. New perspectives in biomolecular paleopathology of ancient tuberculosis: a proteomic approach. $J$ Archaeol Sci 38: 197-201.

Donoghue HD, Marcsik A, Matheson C, Vernon K, Nuorala E, Molto JE, Greenblatt CL, Spigelman M 2005. Co-infection of Mycobacterium tuberculosis and Mycobacterium leprae in human archaeological samples: a possible explanation for the historical decline of leprosy. Proc Roy Soc B 272: 389-394.

Donoghue HD, Spigelman M, Greenblatt CL, Lev-Maor G, Bar-Gal GK, Matheson C, Vernon K, Nerlich AG, Zink AR 2004. Tuberculosis: from prehistory to Robert Koch, as revealed by ancient DNA. Lancet Infect Dis 4: 584-592.

Évinger S, Bernert Zs, Fóthi E, Wolff K, Kővári I, Marcsik A, Donoghue HD, O'Grady K, Kiss K, Hajdu T 2011. New skeletal tuberculosis cases in past populations from Western Hungary (Transdanubia). Homo 62: 165-183.

Fletcher HA, Donoghue HD, Holton J, Pap I, Spigelman M 2003a. Widespread occurrence of Mycobacterium tuberculosis DNA from 18th-19th Century Hungarians. Am J Phys Anthropol 120: 144-152.

Fletcher HA, Donoghue HD, Taylor GM, van der Zanden AGM, Spigelman M 2003b. Molecular analysis of Mycobacterium tuberculosis DNA from a family of 18th century Hungarians. Microbiology 149: 143-151.

Gabler D 1967. Arrabona legkorábbi sigillatái (the earliest sigillatae of Arrabona). Arrabona - Múzeumi Közl 9: 21-53.

Hajdu T, Donoghue HD, Bernert ZS, Fóthi E, Kővári I, Marcsik A 2012. A case of spinal tuberculosis from the middle ages in Transylvania (Romania). Spine 37: e1598-e1601.

Hershkovitz I, Donoghue HD, Minnikin DE, Besra GS, Lee OY-C, Gernaey AM, Galili E, Eshed V, Greenblatt CL, Lemma E, Kahila Bar-Gal G, Spigelman M 2008. Detection and molecular characterization of 9000-year-old Mycobacterium tuberculosis from a Neolithic settlement in the Eastern Mediterranean. PLoS ONE 3: e3426.

Köhler K, Pálfi Gy, Molnár E, Zalai-Gaál I, Osztás A, Bánffy E, Kirinó K, Kiss KK, Mende BG 2012. A late neolithic case of Pott's disease from Hungary. Int J Osteoarchaeol doi: 10.1002/oa.2254.

Manchester K 1983. The archaeology of disease, 1st ed., University of Bradford, Bradford, 99 pp.

Marcsik A, Molnár E, Szathmáry L 2006. The antiquity of tuberculosis in Hungary: the skeletal evidence. Mem Inst Oswaldo Cruz 101 (Suppl. II): 67-71.
Márk L, Gulyás-Fekete G, Marcsik A, Molnár E, Pálfi Gy 2011. Analysis of ancient mycolic acids by using MALDI-TOF MS: response to "Essentials in the use of mycolic acid biomarkers for tuberculosis detection" by Minnikin et al. 2010. J Archaeol Sci 38: 1111-1118.

Márk L, Patonai Z, Váczy A, Loránd T, Marcsik A 2010. Highthroughput mass spectrometric analysis of 1400 -year-old mycolic acids as biomarkers for ancient tuberculosis infection. $J$ Archaeol Sci 37: 302-305.

Masson M, Molnár E, Pálfi Gy, Bartosiewicz L 2008. Palaeopathology of a neolithic population from Southern Hungary. 17th European Meeting of the Paleopathology Association - Diseases of the Past, Copenhagen August 25-27, Abstracts 41-42.

Merczi M 2001. Patológiás jelenségek vizsgálata Visegrád-Diós késő római temetöjében (examination of pathological alterations in the Late Roman Age cemetery of Visegrád-Diós). A Wosinsky Mór Múzeum Évkönyve 23: 25-38.

Nagy M 2003. The early development of Pannonian towns. In Zs Visy (ed.), Hungarian archaeology at the turn of the millennium, Ministry of National Cultural Heritage/Teleki László Foundation, Budapest, p. 221-223.

Ortner DJ 2003. Identification of pathological conditions in human skeletal remains, 2nd ed., Academic Press, Amsterdam-Tokyo, 645 pp.

Pálfi Gy, Dutour O, Deák J, Hutás I 1999. Tuberculosis. Past and present, Golden Book Publishers and Tuberculosis Foundation, Budapest-Szeged, 605 pp.

Pálfi Gy, Marcsik A 1999. Paleoepidemiological data of tuberculosis in Hungary. In Gy Pálfi, O Dutour, J Deák, I Hutás (eds.), Tuberculosis. Past and present, Golden Book Publishers and Tuberculosis Foundation, Budapest-Szeged, p. 533-543.

Pap I, Józsa L, Repa I, Lakhani SR, Donoghue HD, Spigelman M 1999. 18-19th century tuberculosis in naturally mummified individuals (Vác, Hungary). In Gy Pálfi, O Dutour, J Deák, I Hutás (eds.), Tuberculosis. Past and present, Golden Book Publishers and Tuberculosis Foundation, Budapest-Szeged, p. 421-429.

Roberts CA, Buikstra JE 2003. The bioarchaeology of tuberculosis, a global view on a reemerging disease, University Press of Florida, Gainesville, 368 pp.

Rösing FW, Graw M, Marréc B, Ritz-Timmed S, Rothschild MA, Rötzscher K, Schmeling A, Schröder I, Geserick G 2007. Recommendations for the forensic diagnosis of sex and age from skeletons. Homo 58: 75-89.

Shui G, Bendt AK, Pethe K, Dick T, Wenk MR 2007. Sensitive profiling of chemically diverse bioactive lipids. J Lipid Res 48: 1976-1984. 
Stone AC, Wilbur AK, Buikstra JE, Roberts CA 2009. Tuberculosis and leprosy in perspective. Yearb Phys Anthropol 52: 66-94.

Szelekovszky M, Marcsik A 2010. Anthropological analysis of human skeletal material (7-9th century AD, East Hungary). Ann Roum Anthropol 47: 3-15.

Szikossy I, Kustár Á, Guba Zs, Kristóf LA, Pap I 2010. Mummies from Hungary. Naturally mummified corpses from the Dominican Church in Vác, Hungary. In A Wieczorek, W Rosendahl (eds.), Mummies of the world. American Exhibition, Reiss-Engelhorn-Museum, Mannheim-Prestel-Munich-Berlin-London-New York, p. 160-171.
Taylor GM, Crossey M, Saldanha J, Waldron T 1996. Mycobacterium tuberculosis identified in mediaeval human skeletal remains using polymerase chain reaction. J Archaeol Sci 23: 789-798.

Visy Zs 2003a. The Ripa Pannonica in Hungary, Akadémiai Kiadó, Budapest, $175 \mathrm{pp}$.

Visy Zs 2003b. The Roman Army in Pannonia. An archaeological guide of the Ripa Pannonica, Teleki László Foundation, Budapest, $263 \mathrm{pp}$.

Zink A, Haas CJ, Reischl U, Szeimies U, Nerlich AG 2001. Molecular analysis of skeletal tuberculosis in an ancient Egyptian population. J Med Microbiol 50: 355-366. 